\title{
Mechanical Properties and Microstructure of Forged Steels
}

\author{
Andrea Di Schino (1) \\ Dipartimento di Ingegneria, Università Degli Studi di Perugia, via G. Duranti 93, 06125 Perugia, Italy; \\ andrea.dischino@unipg.it
}

Citation: Di Schino, A. Mechanical Properties and Microstructure of Forged Steels. Metals 2021, 11, 1177. https://doi.org/10.3390/met11081177

Received: 25 June 2021

Accepted: 23 July 2021

Published: 24 July 2021

Publisher's Note: MDPI stays neutral with regard to jurisdictional claims in published maps and institutional affiliations.

Forged steels represent a quite interesting material family, both from a scientific and commercial point of view, following many applications they can be devoted to [1]. Following from that, it is, therefore, essential to deeply understand the relations between properties and the microstructure, and how to drive them by process. Despite their diffusion as a consolidated material, many research fields are active regarding new applications. At the same time, innovations are coming from the manufacturing process of such a family of materials. In this framework in particular, the role of heat treatments in obtaining even complex microstructures is still quite an open matter, also thanks to the design of innovative heat treatments [2,3] devoted to forged components [4-7]. The Special Issue scope embraces interdisciplinary work covering physical metallurgy and processes, reporting about the experimental and theoretical progress concerning microstructural evolution during the processing and microstructure-properties relations.

The book collects manuscripts from academic and industrial researchers with stimulating new ideas and original results. The present book consists of three research papers.

$\mathrm{M}$. Algarni in his research analyzes the mechanical properties and fracture behavior of two cold-work tool steels: AISI "D2" and "O1". Tool steels are an economical and efficient solution for manufacturers due to their superior mechanical properties. The demand for tool steels is increasing yearly due to the growth in the transportation production around the world. Nevertheless, AISI "D2" and "O1" (locally made) tool steels behave differently due to the varying content of their alloying elements. There is also a lack of information regarding their mechanical properties and behavior. Therefore, this study aims to investigate the plasticity and ductile fracture behavior of "D2" and "O1" via several experimental tests. The tool steels' behavior under monotonic quasi-static tensile and compression tests was analyzed. The results of the experimental work showed different plasticity behavior and ductile fracture among the two tool steels. Before fracture, clear necking appeared on the "O1" tool steel, whereas no signs of necking occurred on the "D2" tool steel. In addition, the fracture surface of the "O1" tool steel showed a cup-cone fracture mode, and the "D2" tool steel showed a flat-surface fracture mode. The dimple-like structures in scanning electron microscope (SEM) images revealed that both tool steels had a ductile fracture mode [8].

L. Pezzato et al. describe the effects of a second tempering treatment on the microstructural properties and impact toughness of a structural steel EN 10025-6 S690. The steel was first forged and quenched in water after austenitization at $890^{\circ} \mathrm{C}$ for $4 \mathrm{~h}$. After quenching, different tempering treatments were performed, at $590^{\circ} \mathrm{C}$ in single or multiple steps. The effect of these treatments was evaluated both in microstructural terms-by means of optical microscopy scanning, transmission electron microscopy and X-ray diffraction-and in terms of impact toughness. The mechanical behavior was correlated with the microstructure and a remarkable increase in impact toughness was found after the second tempering treatment due to carbide shape change [9].

S. Mancini et al. propose a new approach in order to describe the plastic strain at the core of the piece. FEM takes into account the plastic deformation at the core of the forged pieces. At the first stage, a thermomechanical FEM model was implemented in the MSC Marc commercial code in order to simulate the open die forging process. Starting from 
the results obtained through FEM simulations, a set of equations describing the plastic strain at the core of the piece were identified depending on forging parameters (such as the length of the contact surface between the tools and ingot, tool's connection radius, and reduction in the piece height after the forging pass). An Artificial Neural Network (ANN) was trained and tested in order to correlate the equation coefficients with the forging to obtain the behavior of the plastic strain at the core of the piece [10].

Funding: This research received no external funding.

Acknowledgments: As Guest Editors, I would like to especially thank Harley Wang, Assistant Editor, for his support and his active role in the publication. I am also grateful to the entire staff of the Metals Editorial Office for the precious collaboration. Last but not least, we express our gratitude to all the contributing authors and reviewers: without your excellent work it would not have been possible to accomplish this Special Issue that we hope will be a piece of interesting reading and reference literature.

Conflicts of Interest: The author declares no conflict of interest.

\section{References}

1. Di Schino, A. Manufacturing and application of stainless steels. Metals 2020, 10, 327. [CrossRef]

2. Di Schino, A.; Testani, C. Heat treatment of steels. Metals 2021, 11, 1168. [CrossRef]

3. Mancini, S.; Langellotto, L.; Di Nunzio, P.E.; Zitelli, C.; Di Schino, A. Defect reduction and quality optimization by modeling plastic deformation and metallurgical evolution in ferritic stainless steels. Metals 2020, 10, 186. [CrossRef]

4. Di Schino, A.; Alleva, L.; Guagnelli, M. Microstructure evolution during quenching and tempering of martensite in a medium C steel. Mat. Sci. Forum 2012, 715-716, 860-865. [CrossRef]

5. Di Schino, A.; Di Nunzio, P.E. Metallurgical aspects related to contact fatigue phenomena in steels for back up rolling. Acta Metall. Slovaca 2017, 23, 62-71. [CrossRef]

6. Di Schino, A. Analysis of phase transformation in high strength low alloyed steels. Metalurgija 2017, 56, 349-352.

7. Di Schino, A.; Di Nunzio, P.E.; Turconi, G.L. Microstructure evolution during tempering of martensite in a medium C steel. Mat. Sci. Forum 2007, 558-559, 1435-1441. [CrossRef]

8. Algarni, M. Mechanical properties and microstructure characterization of AISI "D2" and "O1" cold work tool steels. Metals 2019, 9, 1169. [CrossRef]

9. Pezzato, L.; Gennari, C.; Chukin, D.; Toldo, M.; Sella, F.; Toniolo, M.; Zambon, A.; Brunelli, K.; Dabalà, M. Study of the effect of multiple tempering on the impact toughness of forged S690 structural steel. Metals 2020, 10, 507. [CrossRef]

10. Mancini, S.; Langellotto, L.; Zangari, G.; Maccaglia, R.; Di Schino, A. Optimization of open die ironing process through artificial neural network for rapid process simulation. Metals 2020, 10, 1397. [CrossRef] 